\title{
IMPROVED HYDROGEN DETECTION OF ISLAND TYPE PALLADIUM FILM - NANOPOROUS SILICON DIODE AT ROOM TEMPERATURE
}

\author{
V. A. Skryshevsky, V. Polischuk, A. I. Manilov, \\ I. V. Gavrilchenko, R. V. Skryshevsky \\ Radiophysics Faculty, Kyiv National Taras Shevchenko University, \\ 64, Volodymyrska, 01033, Kyiv, Ukraine, tel. +38(044)526-05-23; fax +38(044)526-05-31; \\ e-mail: skrysh@univ.kiev.ua; ir@univ.kiev.ua
}

\begin{abstract}
IMPROVED HYDROGEN DETECTION OF ISLAND TYPE PALLADIUM FILM - NANOPOROUS SILICON DIODE AT ROOM TEMPERATURE
\end{abstract}

\section{A. Skryshevsky, V. Polischuk, A. I. Manilov, I. V. Gavrilchenko, R. V. Skryshevsky}

An island type palladium film - silicon diode hydrogen sensor has been developed applying thin $(15-75 \mathrm{~nm})$ nanoporous silicon as an intermediate sensitive layer. Using a thermal Pd deposition into porous silicon allows to vary the size and morphology of the metal islands in the porous silicon matrix. The gas sensor behaviour under hydrogen exposure in mixture of $200 \mathrm{ppm}-10 \% \mathrm{H}_{2}$ and dry synthetic $\left(20 \% \mathrm{O}_{2}+80 \% \mathrm{~N}_{2}\right)$ air was investigated by measuring the I-V characteristics. The diode current and sensor hydrogen sensitivity is shown to depend on the type of silicon substrate and the thickness of porous silicon. The current change versus hydrogen concentrations shows the linear law both for large and small hydrogen concentrations. At room temperature the sensor sensitivity is approximately $1 \mu \mathrm{A} / 100 \mathrm{ppm}$, the response and recovery times lies in 1-8 min range.

Key words: hydrogen, sensor, porous silicon, sensitivity, room temperature

\section{Анотація}

\section{ПОКРАЩЕННЯ ЧУТЛИВОСТІ ДО ВОДНЮ СТРУКТУРИ ОСТРІВКОВА ПЛІВКА ПАЛАДІЮ-КРЕМНІЕВИЙ ДІОД ПРИ КІМНАТНИХ ТЕМПЕРАТУРАХ}

\section{В. А. Скришевський, В. Полішук, А. І. Манілов, І. В. Гаврильченко, Р. В. Скришевський}

Розроблено сенсор водню на основі структури острівкова плівка палладію - кремнієвий діод, використовуючи тонкий (15-75 нм) шар нанопористого кремнію в якості проміжного чутливого шару. Використання термічного осадження палладію в поруватий кремній дозволяє змінювати розмір та морфологію металевих островків в матриці поруватого кремнію. Поведінка газового сенсора при експозиції водню в суміші 200 ppm- $10 \% \mathrm{H}_{2}$ та сухого синтетичного повітря ( $\left.20 \% \mathrm{O}_{2}+80 \% \mathrm{~N}_{2}\right)$ була досліджена шляхом вимірів вольт-амперних характеристик. Діодний струм і чутливість сенсору водню залежать від типу кремнієвої підкладки і товщини поруватого кремнію. Зміна струму від концентрації водню показує лінійну зале- 
жність для високої та низької концентрації водню. При кімнатній температурі чутливість сенсора складає приблизно 1 мкА/100 ppm, час відгуку та відновлення знаходиться в межах $1-8$ хвилин.

Ключові слова: водень, сенсор, поруватий кремній, чутливість, кімнатна температура

\section{Аннотация \\ УЛУЧШЕНИЕ ЧУВСТВИТЕЛЬНОСТИ К ВОДОРОДУ СТРУКТУРЫ ОСТРОВКОВАЯ ПЛЕНКА ПАЛЛАДИЯ-КРЕМНИЕВЫЙ ДИОД ПРИ КОМНАТНОЙ ТЕМПЕРАТУРЕ}

\section{В. А. Скрышевский, В. Полищук, А. И. Манилов, И. В. Гаврильченко, Р. В. Скрышевский}

Разработан сенсор водорода на основе структуры островковая пленка палладия - кремниевый диод, используя тонкий (15-75 нм) слой нанопористого кремния в качестве промежуточного чувствительного слоя. Использование термического осаждения палладия в пористый кремний позволяет изменять размер и морфологию металлических островков в матрице пористого кремния. Поведение газового сенсора при водородной экспозиции смеси 200 ppm- $10 \% \mathrm{H}_{2}$ и сухого синтетического $\left(20 \% \mathrm{O}_{2}+80 \% \mathrm{~N}_{2}\right)$ воздуха было исследовано путем измерения вольт-амперных характеристик. Диодный ток и чувствительность водородного сенсора зависят от типа кремниевой подложки и толщины пористого кремния. Изменение тока от концентрации водорода показывает линейную зависимость для высокой и для низкой концентрации водорода. При комнатной температуре чувствительность датчика составляет приблизительно 1 мкA/100ppm, время отклика и восстановления находится в пределах 1-8 минут.

Ключевые слова: водород, сенсор, пористый кремний, чувствительность, комнатная температура

\section{Introduction}

It is known the hydrogen is explosive when it mixes with air at above $4.7 \%$. For this reason, among others, it is necessary to develop highly sensitive hydrogen sensors to prevent accidents due to hydrogen - contained gases leakage [1]. Semiconductor devices like resistors, field-effect transistor, metal-semiconductor Schottky barrier, metal-insulator-semiconductor (MIS) capacitor with catalytic metals have been developed over the past twenty five years to detect the hydrogen-contained gases [2-7]. Metal-semiconductor devises utilise the effect of the change in work function of the metal at the interface, because the adsorbed hydrogen atoms form a dipole layer at the interface. The I-V, C-V, impedance and contact potential difference measurements allow to detect the changes in potential barrier height during the hydrogen exposure. However, operating temperature of such sensors achieves $200-500^{\circ} \mathrm{C}$, it corresponds to maximal efficiency of metal catalyst $[8,9]$ that complicates the measuring instruments. Application of $\mathrm{Pd}$ islands as catalyst is a promised way to reduce the operating temperature and improve the hydrogen sensing since: i) the maximal hydrogen dissolubility at room temperature is observed namely for palladium among all catalysts, ii) well-known the island-type catalyst reduces the activation energy to dissociate the hydrogen-contained molecules, iii) the palladium is semitransparent for penetration of hydrogen atoms that allows to accelerate the sensor response and recovery times [3-5].

It should be noted that in the case of silicon MIS structures a thin $(\mathrm{d}<5 \mathrm{~nm})$ oxide layer must be inserted between the metal and semiconductor in order to prevent the formation of palladium silicide, because the silicide formation makes a Pd-Si device totally insensitive to hydrogen [10]. The use of thin porous silicon (PS) instead $\mathrm{SiO}_{2}$ layer it seems to be attractive threefold. A large PS surface area $\left(\sim 500 \mathrm{~m}^{2} / \mathrm{cm}^{2}\right)$ [11] can improve the adsorbate effects, the silicide formation with PS is obscured and observed hydrogen-induced drift in PS sensors response is much less than in $\mathrm{Pd}-\mathrm{SiO}_{2}-$ Si devices [6].

This paper concerns with our efforts to design the current-voltage hydrogen sensor based on island type palladium film - silicon diode with the 
thin nanoporous silicon as intermediate sensitive layer.

\section{Experimental}

The PS layers have been obtained on $\mathrm{n}$ - and p-type (100) Si slab of $4.5 \Omega \cdot \mathrm{cm}$ resistivity by the anodic oxidation in 1:1 HF-Ethanol solution. The added ethanol removes hydrogen bubbles evolving during the reaction, reduces interfacial tension and increases the PS homogeneity. The etching current density was $15 \mathrm{~mA} / \mathrm{cm}^{2}$ for anodization times of 2,5 and $10 \mathrm{~s}$. The thin layers of palladium were deposited on PS by thermal evaporation under vacuum conditions through metal mask having round windows of 1 or $2 \mathrm{~mm}$ diameters. The palladium filament mass for deposition was calculated before to obtain $\sim 5 \mathrm{~nm}$ film. AFM study shows the the palladium clusters of $50 \mathrm{~nm}$ in diameter on the rough surface of PS. A $0.5 \mu \mathrm{m}$ Au Ohmic contact was deposited electrochemically on polished rear side of Si slab. In order to make the front contact, the copper wire was glued by the silver paste on the round palladium windows of $2 \mathrm{~mm}$. Estimated series resistance of structures is approximately $50 \Omega$. To exclude the water adsorption the steady state I-V curves have been measured in dry synthetic $\left(20 \% \mathrm{O}_{2}+80 \% \mathrm{~N}_{2}\right)$ air or synthetic air diluted by pure hydrogen.

\section{Results and Discussion}

Figure 1 shows the I-V characteristics of Ag-PdPS-Si-Au Schottky diodes for different PS thicknesses and two types of Si slabs. Both the Pd-PS-(n)Si and Pd-PS-(p)Si structures display the rectifying type of the I-V characteristics. It indicates that the Pd forms the build in potential barrier both on (n)Si and (p)Si wafers. The value of the potential barrier defined from saturation current $e \varphi_{b}=0.35 \mathrm{eV}$ on (n)Si and $0.30 \mathrm{eV}$ on (p)Si. These curves demonstrate too the deterioration of rectification properties with the porous silicon thickness growth which changed from $15 \mathrm{~nm}(\mathrm{t}=2 \mathrm{~s})$ to $75 \mathrm{~nm}(\mathrm{t}=10 \mathrm{~s})$.

Figure 2 shows the influence of hydrogen exposure $\left(10 \% \mathrm{H}_{2}+\right.$ synthetic air) on I-V characteristics of elaborated structures. The hydrogen adsorption increases both the forward and reverse currents for Pd-PS-(n)Si structure and decreases these currents for Pd-PS-(p)Si structure with respect to sign of Schottky contact and increased positive charge in interface. Figure 3 shows the dynamic response of Pd-PS-(n)Si and Pd-PS-(p)Si junctions exposed to successively injected $\mathrm{H}_{2}$ concentrations. It is necessary 200-300 s, approximately, to saturate the current response for given hydrogen concentration. Figure 4 gives the device sensitivity as function of hydrogen concentration. These dependencies appear the linear sensitivity behaviour on hydrogen concentration.

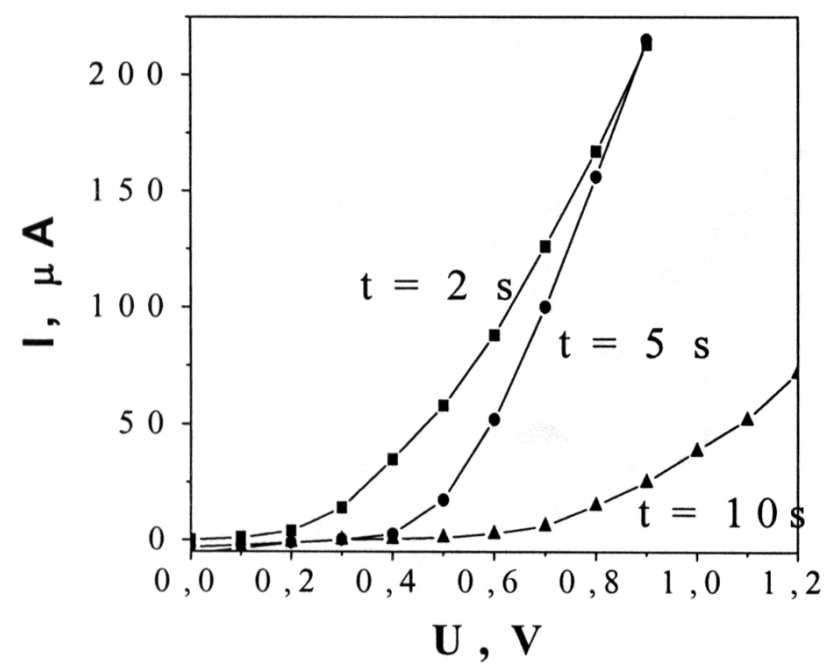

a)

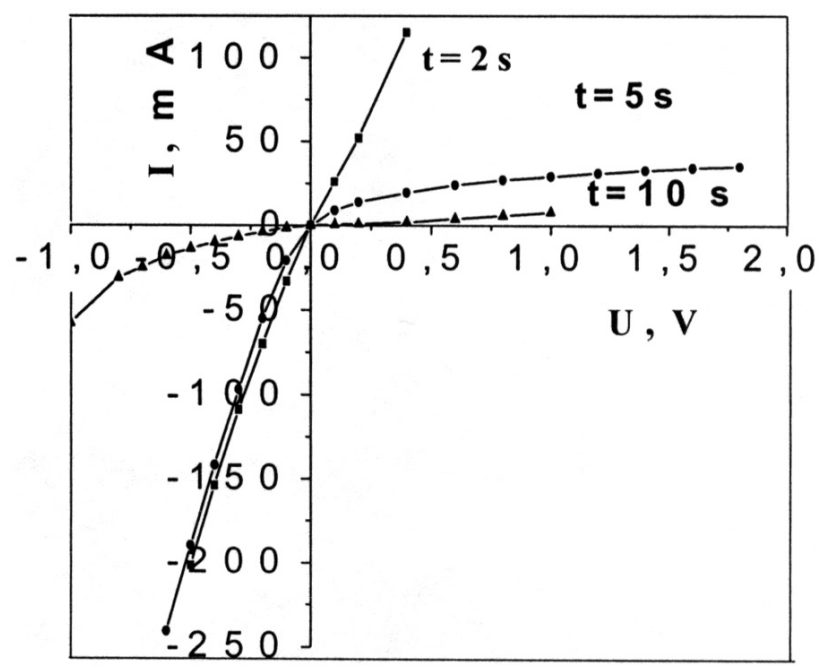

b)

Fig. 1. I-V characteristics of (5nm)Pd-Si-(n)Si) (a) and $(5 \mathrm{~nm}) \mathrm{Pd} / \mathrm{PS} /(\mathrm{p}) \mathrm{Si} / \mathrm{Au})$ (b) diodes with different thicknesses of PS. The anodized was carried out in the solution of $(48 \%) \mathrm{HF}: \mathrm{Et}=1: 1$, at $\mathrm{j}=15 \mathrm{~mA} / \mathrm{cm}^{2}$ during $\mathrm{t}=2,5$ and $10 \mathrm{~s}$

The kinetic of current response is presented in Figure 5. A good reproducibility of current response $\mathrm{S}=\Delta \mathrm{I} / \mathrm{I}_{0}$ is observed. Generally, the response time can be defined as the time for which the sensitivity achieves of $90 \%$ of its final response: $\mathrm{S}\left(\mathrm{t}=\mathrm{t}_{\mathrm{res}}\right)=90 \%$ $\mathrm{S}(\mathrm{t}=\propto)$. The recovery time is defined as time for which the sensitivity recovers $90 \%$ of its equilibrium 
value: $\mathrm{S}\left(\mathrm{t}=\mathrm{t}_{\text {rec }}\right)=10 \% \mathrm{~S}(\mathrm{t}=\propto)$. The response time is 2 min for (p)Si and 8 min for (n)Si. By contrary, the recovery time for $(\mathrm{p}) \mathrm{Si}(5 \mathrm{~min})$ is bigger than for (n) $\mathrm{Si}$ (1 min).

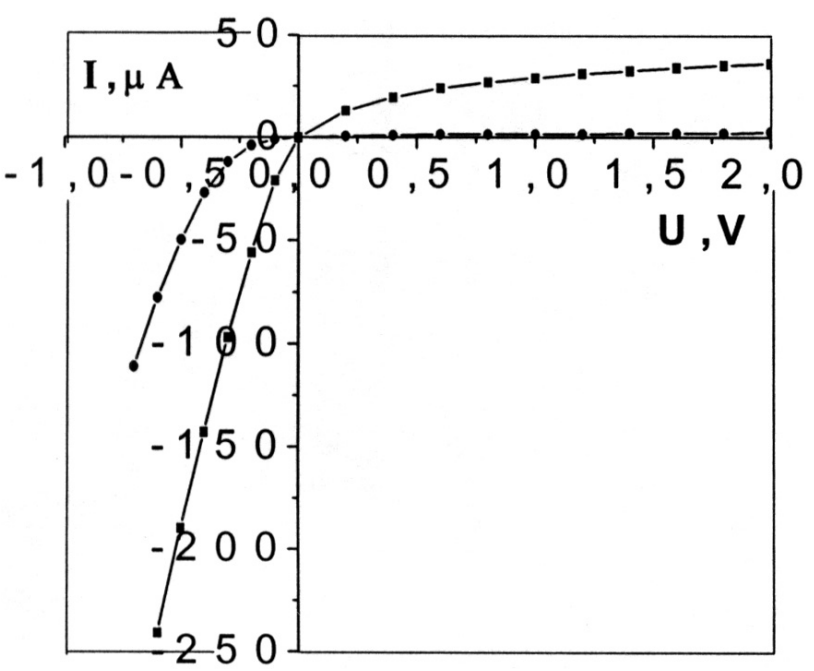

a)

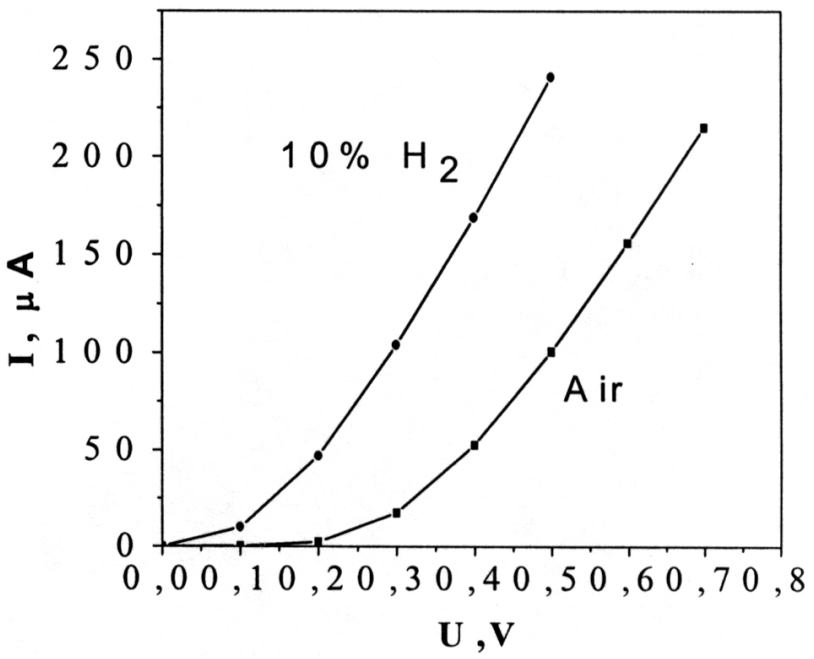

b)

Fig. 2. The I-V characteristics in synthetic air and synthetic air with $10 \%$ of $\mathrm{H}_{2}$ for (a) $\left.(5 \mathrm{~nm}) \mathrm{Pd} / \mathrm{PS} /(\mathrm{p}) \mathrm{Si} / \mathrm{Au}\right)$ and (b) (5nm) Pd/PS/(n)Si/Au) diodes

In general, a gas sensor is said to have good sensitivity when it exhibits both of the the following properties:1) it has a high signal- to noise ratio, extremely at low partial pressure of gas to be detected, and 2) it is sensitive to the gas to be detected over a wide range of partial pressure [2,8]. Figure 6 presents the current changes as function of time for Pd-PS-(n)Si structures exposed to small hydrogen concentrations from $200 \mathrm{ppm}$ to $1000 \mathrm{ppm}$ in air. The current changes versus small hydrogen concentrations shows the linear sensitivity behaviour as in the case of large hydrogen concentrations. In this case, the sensitivity was $1.2 \mu \mathrm{A} / 100 \mathrm{ppm}$. Thus, in all concentrations range of hydrogen until $[\mathrm{H} 2]<6 \%$ the sensitivity is linear.

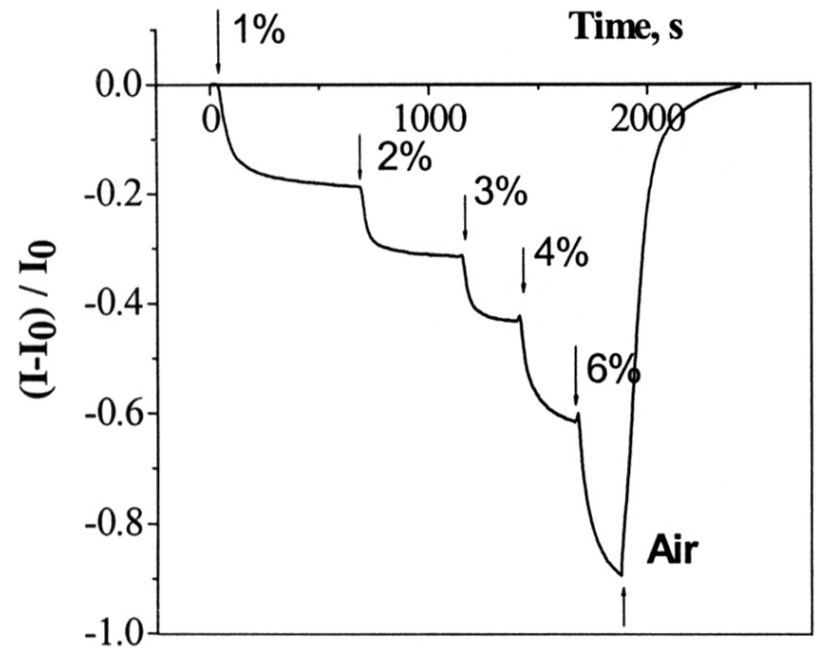

a)

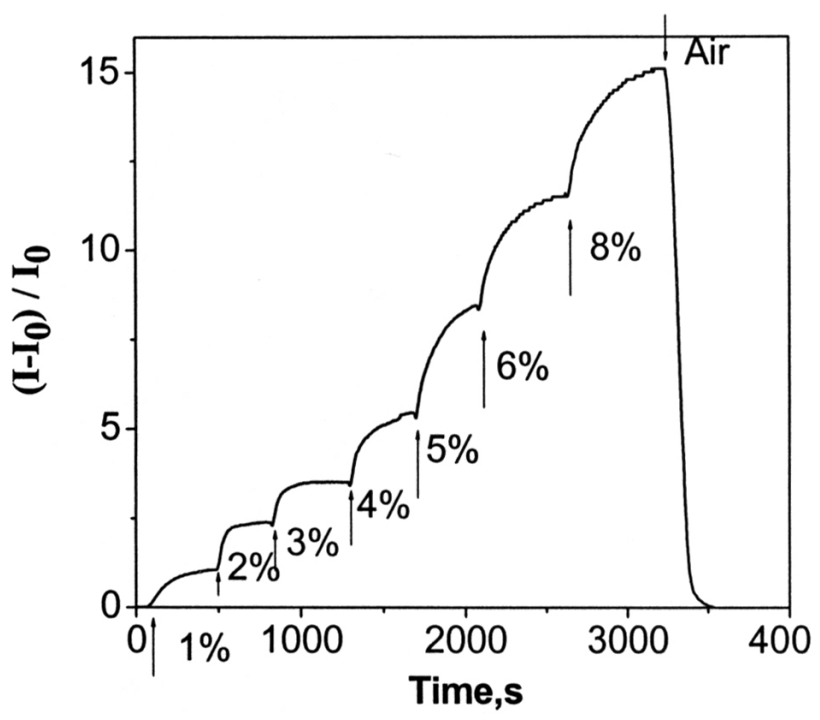

b)

Fig. 3. Current responses as function of time for (a) (5nm)Pd-(5s)PS-(p)Si and (b) (5nm)Pd-(5s)PS-(n)Si diodes under successively injected hydrogen concentrations

The sensor sensitivity evolution as function of its aging (the second measure was made in 14 days after the first) is shown on figure 7 . There is the reduction of sensor current with aging in ambient atmosphere. The porous silicon aging under the ambient conditions was observed in [12] by IR spectroscopy. The study of vibrating modes of Si$\mathrm{H}$ and $\mathrm{Si}-\mathrm{O}-\mathrm{Si}$ in infrared region in porous silicon has revealed the development from time of Si-O$\mathrm{Si}$ absorption modes. This oxide growth explains the effect of current reducing. However, since the slop of curve current versus hydrogen concentration 
does not change, the sensitivity of sensor remains the same with time. Moreover, by contrary to PS sensors with opened surface the metal covering prevents the effect of surface oxidation.

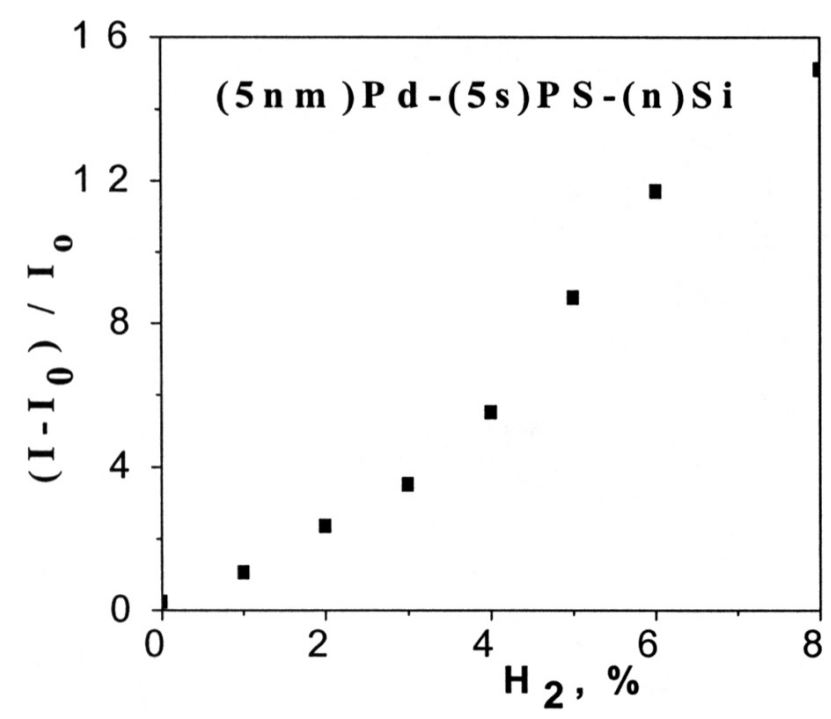

a)

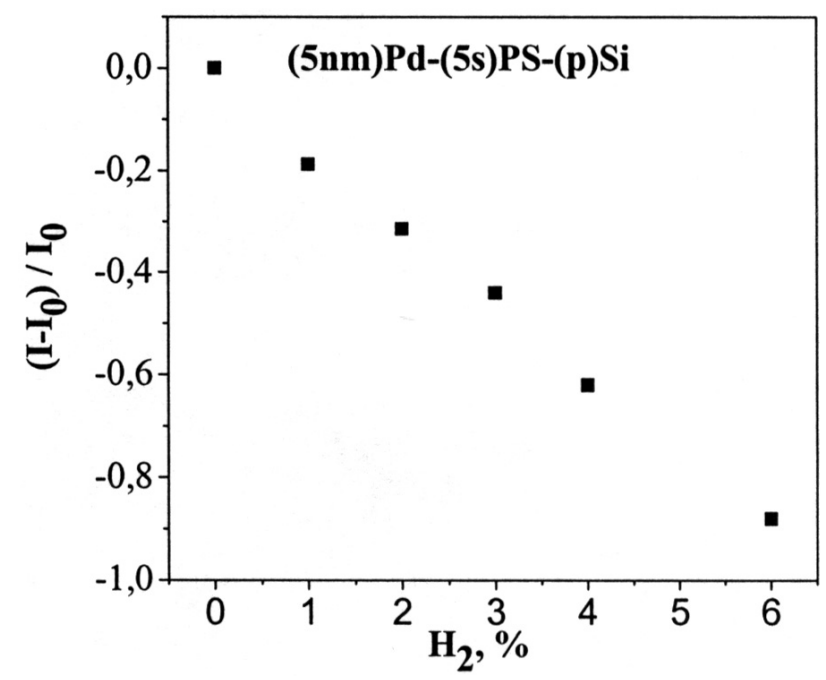

b)

Fig. 4. The Pd-PS-Si diode sensitivity versus the hydrogen concentration

According to [3-5], the hydrogen sensing mechanism includes the adsorption and dissociation of hydrogen molecules in the Pd, the transport of hydrogen atoms across the catalytic metal film and the formation of dipoles at the metal-insulator interface. To explain the dependence of the I-V characteristics on hydrogen concentration we can apply the model of Schottky contact with the PS and $\mathrm{SiO}_{2}$ interface layer [13]. Then the I-V characteristics can be given by

$$
\mathrm{I}=\mathrm{I}_{\mathrm{s}}\left[\exp \left(\mathrm{eU_{ \textrm {s } }} / \mathrm{kT}\right)-\exp \left(-\mathrm{e} \mathrm{U}_{\mathrm{l}} / \mathrm{kT}\right)\right],
$$

where $\mathrm{U}=\mathrm{U}_{\mathrm{s}}+\mathrm{U}_{1}, \mathrm{U}_{\mathrm{s}}$ and $\mathrm{U}_{1}-$ parts of voltage drops on Si and PS, respectively, the dark saturation current $I_{s}$ is expressed via the barrier heights and the effective coefficient of transparency of PS interface. If for well-studied $\mathrm{Pd}-\mathrm{SiO}_{\mathrm{x}}-\mathrm{Si}$ devices [5] the change in the diode barrier height describes the alteration in the diode current density at the hydrogen adsorption. However, for Pd-PS-(p)Si device the experimental change of I-V characteristics at hydrogen adsorption is not fitted by variation of barrier height. There is the dependence of adsorption effect $\left(\mathrm{I}-\mathrm{I}_{\mathrm{o}}\right) / \mathrm{I}_{\mathrm{o}}$ on applied voltage, when $\left(\mathrm{I}-\mathrm{I}_{\mathrm{o}}\right) / \mathrm{I}_{\mathrm{o}}$ decreases at the increase of forward voltage biases, and linear dependence of $\left(\mathrm{I}-\mathrm{I}_{\mathrm{o}}\right) / \mathrm{I}_{\mathrm{o}}$ on hydrogen concentration (Fig.4). To explain the experimental results we account the surface states insides of pores and/or at PS-Si and $\mathrm{PS}-\mathrm{SiO}_{2}$ interfaces that was done before in $[14,15]$.

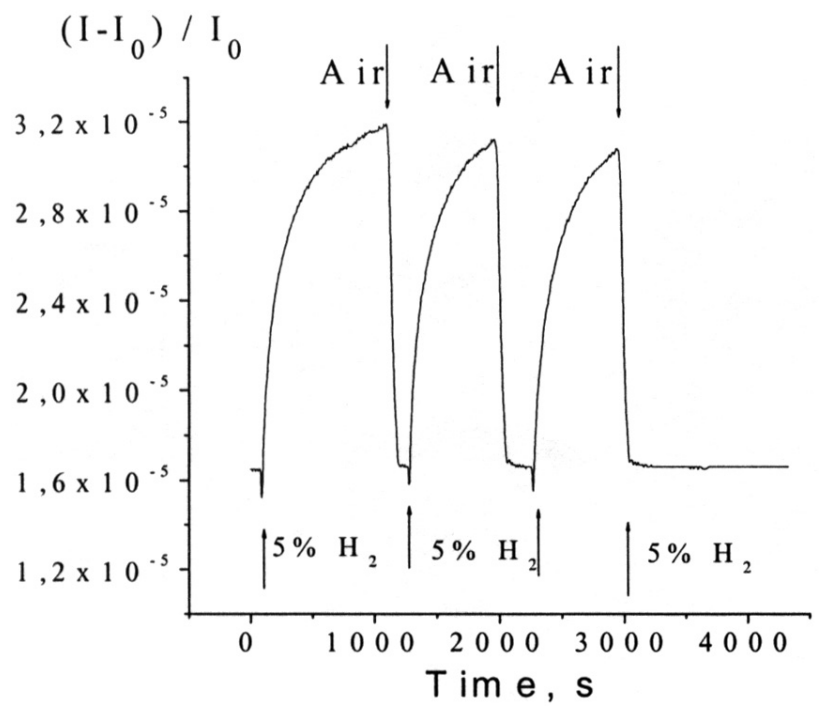

a)



b)

Fig. 5. Temporal response of (a) (5nm)Pd-(5s)PS-(n)Si and (b) $(5 \mathrm{~nm}) \mathrm{Pd}-(5 \mathrm{~s}) \mathrm{PS}-(\mathrm{p}) \mathrm{Si}$ under $5 \% \mathrm{H}_{2} /$ air cycles 


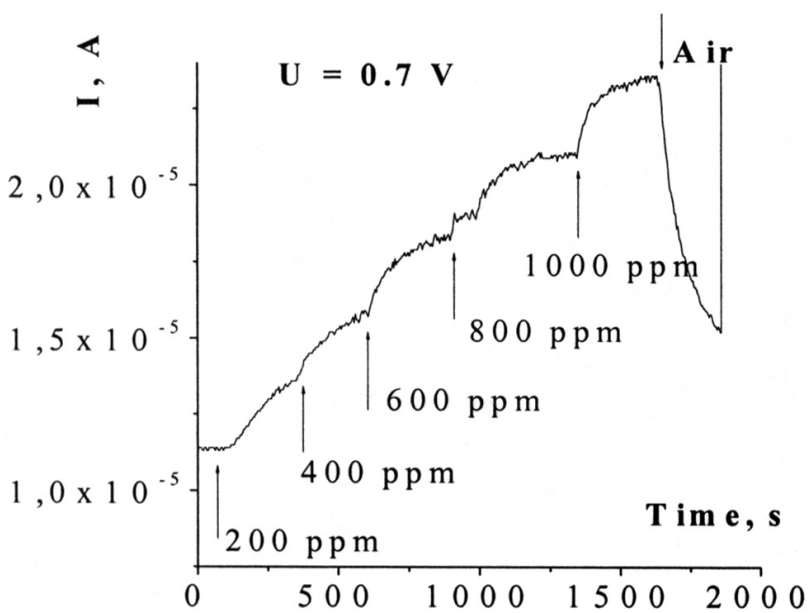

a)

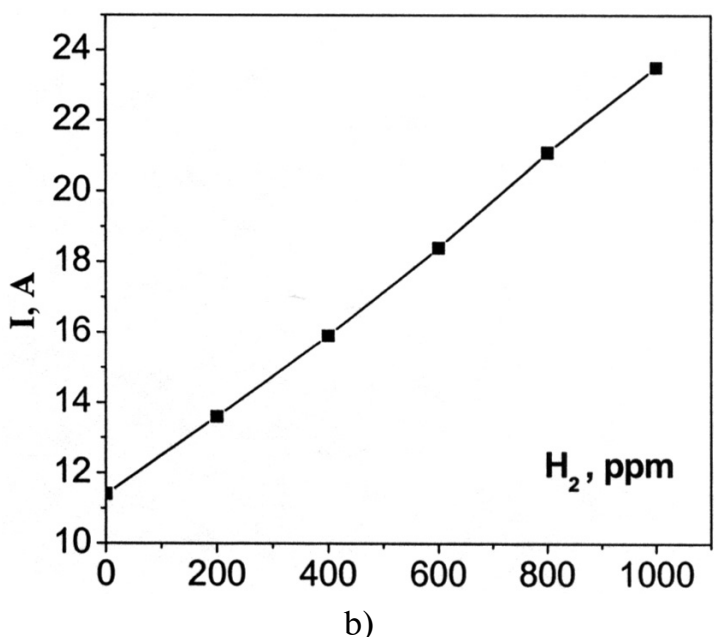

Fig. 6. Current kinetics as function of time for $(5 \mathrm{~nm}) \mathrm{Pd}-$ (5s)PS-(n)Si structure under small hydrogen concentrations in air (a) and sensitivity versus the small hydrogen concentration (b)

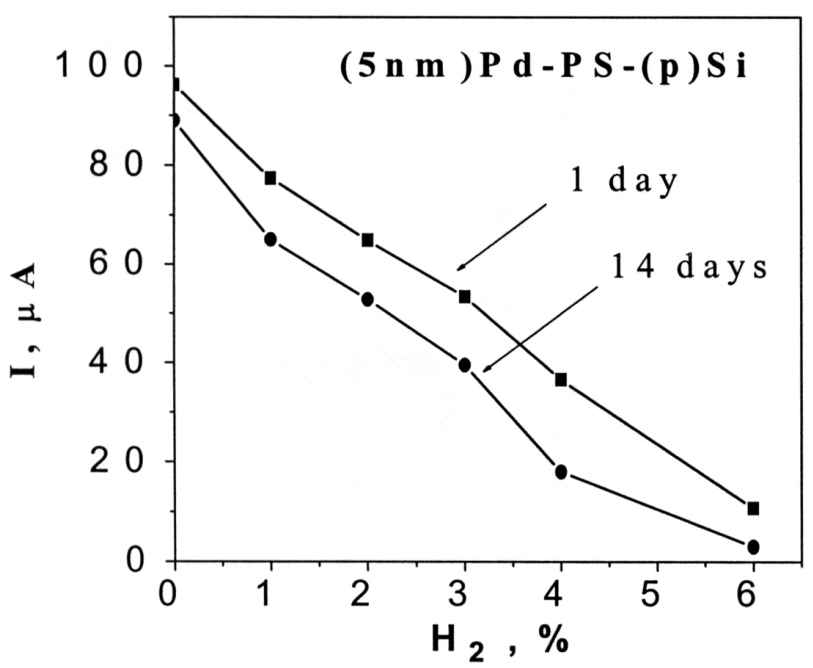

Fig. 7. Sensor current versus hydrogen concentration 1day and 14 days after structure formation

\section{Conclusion}

The I-V curves of Ag- $(5 \mathrm{~nm}) \mathrm{Pd}-(15-75 \mathrm{~nm}) \mathrm{PS}-$ $\mathrm{Si}$-Au structures show the Schottky-type behaviour both for (n) and (p)Si wafers with build- in potential $0.3-0.35 \mathrm{eV}$. The insertion of thin PS instead of ultrathin $\mathrm{SiO}_{x}$ interface layer (as is typically used in such kind of devices) prevents the palladium silicide formation and permits to form the palladium islands-type covering. The proposed sensor exhibits the sensing to hydrogen exposure in wide range of $\mathrm{H}_{2}$ concentration from $200 \mathrm{ppm}-10 \%$ in synthetic air and linear response at the room temperature operation with slop 1.2 $\mu \mathrm{A} / 100 \mathrm{ppm}$. The hydrogen detection mechanism is described in frame of Schottky model with isolator interface.

\section{Acknowledgements}

This work has been funded in part by INTAS program (project 05-1000005-7729) and Science \& Technology Center in Ukraine under contract STCU N3819 and Ministry of Education and Scince of Ukraine (projects DZ/353-2007, F25/131-2008).

\section{References.}

1. A.Mandelis, C.Christofides, In: Chemical Analysis /A series of monographs on analytical chemistry and its applications/, v. 125, ed.J.D.Winefordner, Wiley \&Sons, N.Y., 1990.

2. Sensors (A Comprehensive Book Series): Chemical and Biochemical Sensors / eds W.Gopel, J.Hesse, J.N. Zemel. - Weinheim.: VCH, 1991. - V.2. P.469-523.

3. Lundstrom I. // Sensors and Actuators. - 1981. V.1. - P. 403-426.

4. Lundstrom I., Soderberg D. // Sensors and Actuators. - 1981/1982. - V.2. - P.105-138.

5. Zheng Li, S.J.Fonash, In Chemical Sensor Technology, Vol.2, Tokyo, 1989, pp.21-41.

6. V.Polishchuk, E.Souteyrand, J.R.Martin, D.Nicolas, V.I.Strikha, V.A.Skryshevsky, Anal.Chem.Acta, 375, 205 (1998).

7. V.G. Litovchenko, T.I. Gorbanyuk, V.S. Solntsev, A.A. Evtukh, Appl. Surf. Sci. 234 (2004) 262-267.

8. D.Kohl, J.Phys.D :Apl.Phys.34(2001) R125-R149

9. В.А.Скришевський, Фізичні основи напівпровідникових хімічних сенсорів, Київ, Київський університет, 2006.

10. M.C.Steele and B.A.Maciver, Appl .Phys.Lett., 28, 687 (1976). 
11. Bisi O., Ossicini S., Pavesi L. Surface Sci.Reports. 2000. - V.38. - P.1-126.

12. Valeri P. Tolstoy, Irina Chernyshova, Valeri A. Skryshevsky, Handbook of Infrared Spectroscopy of Ultrathin Films, John Wiley \& Sons, Inc., N.J., 2003, $710 \mathrm{p}$.

13. V.A.Vikulov, V.I. Strikha, V.A. Skryshevsky,
S.S.Kilchitskaya, E.Souteyrand, J. - R. Martin, J.Phys.D, 33, 1957-1964, 2001.

14. V.A.Skryshevsky, V.M.Zinchuk, A.I.Benilov, Yu.S.Milovanov, O.V.Tretyak. Semicond. Sci. Technol., 21, 2006, pp.1605-1608.

15. O.V. Tretyak, V.A.Skryshevsky, V.A.Vikulov, Yu.V.Boiko, V.M.Zinchuk, Thin Solid Films, 445 (2003) 144-148. 